\title{
Delayed Wilting of Tomato Plants by Chemical Closure of Stomata
}

\author{
by D. Mishra* and G. C. PradHAN*
}

Received December, 14, 1967

\begin{abstract}
The growth retardants $\mathrm{CCC}$ and B-Nine, and the fungicides PMA and 8-HQ when sprayed to young tomato plants reduced the transpiration water loss by 20 $35 \%$, induced a reduction in stomatal width by $10-33 \%$ and delayed the wilting of plants due to soil drought by about a week. The order of effectiveness of these chemicals in inducing stomatal closure and in delaying the wilting of plants is: $\mathrm{PMA}>\mathrm{CCC}>\mathrm{B}-\mathrm{Nine}>8-\mathrm{HQ}$. The significance and the mechanism of the chemical closure of stomata in relation to the survival of plants under conditions of soil drought is discussed.
\end{abstract}

Wilting of plants can be delayed by reducing the transpiration water loss. There are a number of possible practical approaches to the problem of reducing transpiration $^{1)}$ of which the materials causing stomatal closure is important because stomatal transpiration accounts for the main loss of water from plants. Certain growth retardants such as $\mathrm{CCC}$ and $\mathrm{B}-\mathrm{Nine}$ reduce plant water stress and also the transpiration growth ratio (Halevy and Kessler ${ }^{2}$. A comprehensive review on the physiology of growth retarding chemicals has appeared (Cathey) ${ }^{3)}$.

Zelitch and his coworkers ${ }^{4,5,6)}$ have investigated the effect of fungicides such as PMA and metal chelate $8-\mathrm{HQ}$ on stomatal aperture, transpiration and photosynthesis of tobacco, corn and sunflower plants. They demonstrated that transpiration could be reduced relatively more than photosynthesis by chemically induced stomatal closure ${ }^{7)}$.

A perusal of the relevant literature shows that these chemicals can reduce transpiration by closing the stomata. As such, the response of tomato plants to foliar application of these chemicals with regard to transpiration water loss, stomatal distribution, aperture width, percentage stomata closed and the days required to wilting have been studied.

\section{Material and Methods}

Tomato (Lycopersicon esculentum Mill. Cultivar-Marglobe 30 days old, average height $13.16 \mathrm{~cm}$, fresh weight $3.71 \mathrm{~g}$ ) seedlings were transplanted to waxed paper cups containing $500 \mathrm{~g}$ of garden soil. There were four treatments besides the control and each treatment was replicated seven times. The containers were arranged in a randomized block design on the laboratory table under diffused light. The trans-

* Department of Botany, College of Agriculture, Orissa University of Agriculture \& Technology, Bhubaneswar-3, Orissa, India.

** The following abbreviations are used: ATP (Adenosine tri-phosphate), B-Nine ( $\mathrm{N}$ dimethylamino succinamic acid), CCC (2-chloroethyl-tri-methylammonium chloride), 8-HQ (8Hydroxyquinoline) and PMA (Phenylmercuric acetate). 
plants were allowed to establish which was about two days. The soil surface was covered by polythene paper through which the stalks projected. Sufficient water was added to the paper cups before sealing to bring the soil to field capacity. The chemicals were sprayed at the desired concentrations. The water lost by transpiration was measured by daily weighings. The test chemicals were CCC, B-Nine $\left(5 \times 10^{-3} \mathrm{M}\right)$, PMA $\left(10^{-4} \mathrm{M}\right)$ and $8-\mathrm{HQ}\left(10^{-3} \mathrm{M}\right)$ which were sprayed with an atomizer in the afternoon. Teepol (B. D. H.) was added as wetting agent to the spray solution except those of CCC and B-Nine. $10 \mathrm{~m} l$ of the test solution was sprayed to each of the plants and the spray was given twice throughout the experimental period. The control plants were sprayed with distilled water containing teepol.

Stomatal opening was measured after the method of Zelitch ${ }^{4)}$. The leaf desiccation followed by inward rolling of lamina was considered to be the first visible symptom of wilting damage. Permanent wilting was considered when all the leaves were desiccated and began drooping.

\section{Experimental Results}

1. Observation on transpiration.

The results on transpiration water loss from the plants of the control series and of the treated plants are presented in Table 1. During the test period of one week all the four chemicals significantly. $(\mathrm{P}<1 \%)$ reduced the transpiration water loss.

The course of transpiration of the tomato seedlings of the control series for this period of one week is presented graphically in Fig. 1. A linear relationship exists between the water loss with the advancing time. This indicates that the environmental factors did not alter significantly during this period. The $\%$ reduction in transpiration of the treated plants with the advancing time is given in Fig. 2. After $24 \mathrm{hrs}$ of spray application, the transpiration rates of the treated plants are greatly reduced. The water lost by transpiration is reduced to the extent of $35 \%$ by PMA, $22 \%$ by CCC, $25 \%$ by B-Nine and $19 \%$ by $8-\mathrm{HQ}$ application, during $24 \mathrm{hrs}$. Another spray application after three days does not further reduce the transpiration water loss, but on the other hand shows a slight increase, which gradually levels off to a value which is still significantly below the value for the control plants. The mean

Table 1. Transpiration water loss of Tomato seedlings due to treatment. Each value is the mean of seven plants \pm standard deviation. Value represented as water transpired during the test period ( $\mathrm{gm} / \mathrm{plant})$.

\begin{tabular}{l|c|c|c|c|c|c|c}
\hline \multirow{2}{*}{ Treatment } & \multicolumn{7}{|c}{ Test period in days } \\
\cline { 2 - 8 } & 1 & 2 & 3 & 4 & 5 & 6 & 7 \\
\hline Control & $16.1 \pm 2.3$ & $26.9 \pm 1.7$ & $38.2 \pm 4.7$ & $45.0 \pm 3.9$ & $51.9 \pm 2.1$ & $58.0 \pm 9.1$ & $64.3 \pm 6.3$ \\
CCC $\left(5 \times 10^{-3} \mathrm{M}\right)$ & $12.2 \pm 2.8$ & $19.8 \pm 2.1$ & $27.8 \pm 3.0$ & $33.9 \pm 4.2$ & $40.9 \pm 5.1$ & $48.3 \pm 5.5$ & $53.7 \pm 3.5$ \\
B-Nine $\left(5 \times 10^{-3} \mathrm{M}\right)$ & $12.1 \pm 1.9$ & $19.1 \pm 4.4$ & $27.0 \pm 3.1$ & $32.8 \pm 4.5$ & $39.1 \pm 5.8$ & $47.2 \pm 3.7$ & $52.5 \pm 3.6$ \\
PMA $\left(10^{-4} \mathrm{M}\right)$ & $10.5 \pm 1.2$ & $16.9 \pm 1.9$ & $25.3 \pm 3.1$ & $32.6 \pm 3.7$ & $37.8 \pm 4.2$ & $46.7 \pm 4.8$ & $51.9 \pm 5.2$ \\
8-HQ $\left(10^{-3} \mathrm{M}\right)$ & $13.0 \pm 1.1$ & $21.6 \pm 3.3$ & $30.4 \pm 4.1$ & $36.3 \pm 4.7$ & $42.2 \pm 5.1$ & $48.5 \pm 3.7$ & $54.8 \pm 9.3$ \\
L.S. D. (0.01) & 3.02 & 4.45 & 5.48 & 5.29 & 7.10 & 8.61 & 9.12 \\
\hline
\end{tabular}

All values for the treated series are significantly different from the control at $1 \%$ level by the Duncan's Multiple Range Test. 
transpiration reduction over this one week test period is about $30 \%$ for PMA, $24 \%$ for CCC, $22 \%$ for $\mathrm{B}-\mathrm{Nine}$ and $18 \%$ for $8-\mathrm{HQ}$ treatments.

2. Observation on stomatal distribution and opening.

This observation was undertaken in order to correlate the reduction of transpiration with the stomatal opening of leaves. Before studying the width of stomatal aperture of the treated plants, an investigation was undertaken regarding the distribution and aperture width of stomata in the top leaflets of leaves from different nodes of the tomato plant. This was studied to know whether any difference exists in the distribution and width of stomata situated at different heights from the soil surface. The data presented in Table 2 show the distribution and aperture width of the stomata of the terminal leaflet from the leaves at nodes fourth to eighth, the node at the soil surface being taken as zero. The data indicate that there is approximately double the number of stomata on the lower surface than at the upper surface. It is also evident that the number of stomata are more towards the top of

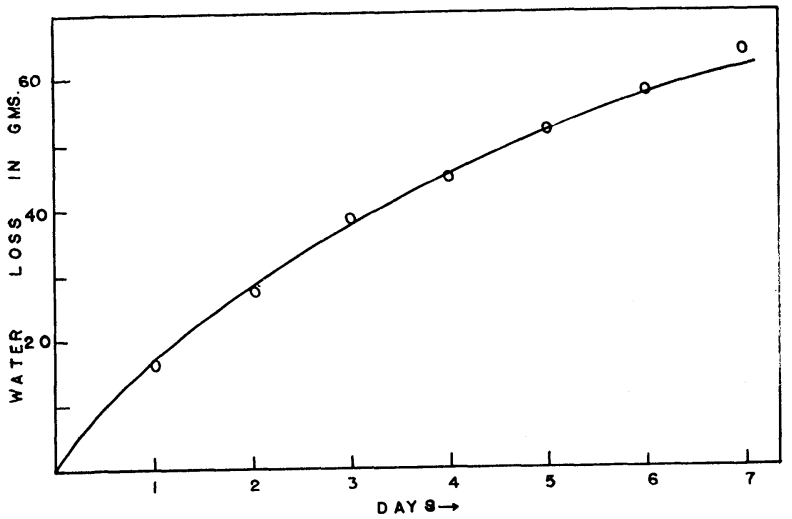

Fig. 1. The course of transpiration in tomato plants of the control series.

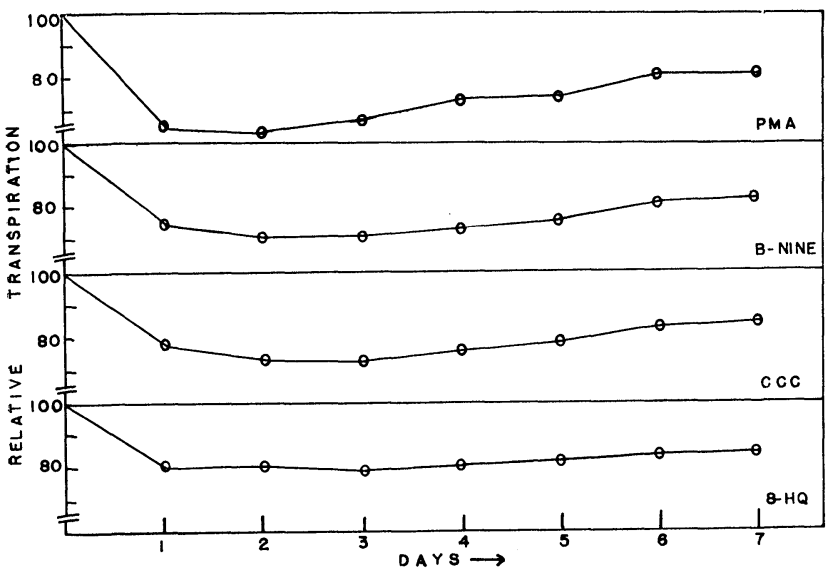

Fig. 2. Transpiration of treated plants as $\%$ of control. 
the plant than towards the base. No significant difference is noted in the width of stomatal opening but generally the aperture is more wider at the lower surface of the leaves.

As the stomatal distribution is more towards the apex, the stomatal study was confined only to the terminal leaflet of the third expanded leaf from the apex. This was studied at 14 days after the first spray application. The values tabulated in Table 3 indicate the reduction in stomatal aperture in all the treatments, the reduction in stomatal opening being directly related with the reduction in transpiration. PMA induced a reduction of stomatal width to the extent of $33 \%$, CCC and B-Nine by $20 \%$ and $8-\mathrm{HQ}$ by 10 to $18 \%$ only.

\section{Observation on wilting of plants.}

The first visible sign of wilting was noted in the plants from the control series. The number of wilted plants were recorded daily. The wilting percentage and the days required to $50 \%$ wilting of plants are presented in Table 4 .

The results indicate that the foliar application with these chemicals increases the resistance of plants to wilting. There is a delay in the wilting of plants and the effect of these chemicals in making the plants resistant to wilting in a decreasing order is as follows: $\mathrm{PMA}>\mathrm{CCC}>\mathrm{B}-\mathrm{Nine}>8-\mathrm{HQ}$.

Table 2. Distribution and aperture width of stomata on terminal leaflets of leaves from different nodes of the Tomato (variety-Marglobe) plant. Node is numbered from below upwards, the node at the soil surface being taken as zero.

\begin{tabular}{c|r|r|r|r}
\hline \multirow{2}{*}{ Node number } & \multicolumn{2}{|c|}{ No. of stomata per sq. mm. } & \multicolumn{2}{c}{ Stomatal aperture in $\mu$} \\
\cline { 2 - 5 } & Upper surface & Lower surface & Upper surface & Lower surface \\
\hline 4 & $72.5 \pm 11.5$ & $138.5 \pm 16.1$ & $5.86 \pm 0.95$ & $7.44 \pm 1.25$ \\
5 & $88.8 \pm 12.4$ & $141.3 \pm 14.5$ & $6.65 \pm 0.61$ & $7.96 \pm 1.33$ \\
6 & $106.3 \pm 13.5$ & $193.8 \pm 17.9$ & $7.61 \pm 1.17$ & $8.58 \pm 1.29$ \\
7 & $106.3 \pm 10.6$ & $178.8 \pm 23.6$ & $8.40 \pm 1.18$ & $7.79 \pm 1.39$ \\
8 & $107.5 \pm 10.5$ & $210.0 \pm 27.5$ & $5.69 \pm 0.61$ & $7.44 \pm 1.25$
\end{tabular}

Each value is the mean of 10 stomata \pm standard deviation.

Table 3. Width of stomata in Tomato leaflet (terminal leaflet of the third leaf from the apex of the 50 days old plant) 14 days after spray application.

\begin{tabular}{l|c|c|c|c}
\hline \multirow{2}{*}{ Treatments } & \multicolumn{2}{|c|}{ Stomatal aperture in $\mu$} & \multicolumn{2}{c}{ Reduction in width (\%) } \\
\cline { 2 - 5 } & Upper surface & Lower surface & Upper & Lower \\
\hline Control & $3.50 \pm 0.58$ & $3.85 \pm 0.68$ & - & - \\
CCC $\left(5 \times 10^{-3} \mathrm{M}\right)$ & $2.97 \pm 0.45$ & $3.06 \pm 0.62$ & 15 & 20 \\
B-Nine $\left(5 \times 10^{-3} \mathrm{M}\right)$ & $2.80 \pm 0.44$ & $3.06 \pm 0.46$ & 20 & 20 \\
PMA $\left(10^{-3} \mathrm{M}\right)$ & $2.36 \pm 0.43$ & $2.54 \pm 0.27$ & 33 & 34 \\
8-HQ $\left(10^{-4} \mathrm{M}\right)$ & $3.15 \pm 0.74$ & $3.15 \pm 0.59$ & 10 & 18 \\
\hline L.S. D. $(0.05)$ & 0.54 & 0.52 & & \\
L.S. D. $(0.01)$ & 0.72 & 0.44 & & \\
\hline
\end{tabular}


The plants in the control series show the visible sign of wilting after eight days, whereas in the plants treated with PMA these signs are noted sixteen days after cessation of watering. Ten days afterwards $50 \%$ of the control plants wilt permanently but in PMA treated plants none show permanent wilting. After further fifteen days, all the plants of the control series wilt but only $70 \%$ of the PMA treated plants wilt by that time. A photograph (Fig. 3) taken at eleven days after cessation of watering clearly shows the turgidity of leaves in the treated plants compared to the leaf desiccation and partial wilting manifested by the control plant.

The days required to $50 \%$ wilting of the plant population are delayed for 9 days by PMA, 7 days by CCC, 6 days by B-Nine and about a day only by 8-HQ application. These observations clearly indicate that PMA, CCC and B-Nine treatments can prevent leaves from wilting under conditions where the leaves from the control plants wilt badly. Hence it can be inferred that tomato plants show delayed wilting by reducing transpiration through the chemical-induced closure of stomata.

Table 4. Resistance to wilting of tomato plants to soil drought due to treatments.

\begin{tabular}{l|r|r|r|r|r}
\hline \multirow{2}{*}{ Treatments } & \multicolumn{3}{|c|}{$\%$ permanently wilted plants } & \multirow{2}{*}{$\begin{array}{c}\text { Days required when } \\
50 \% \text { plants wilt }\end{array}$} \\
\cline { 2 - 5 } & \multicolumn{3}{|c|}{ Days after spray } \\
Control & 20 & 25 & 30 & 35 & 19 \\
CCC $\left(5 \times 10^{-3} \mathrm{M}\right)$ & 60 & 80 & 90 & 100 & 26 \\
B-Nine $\left(5 \times 10^{-3} \mathrm{M}\right)$ & 10 & 30 & 60 & 80 & 25 \\
PMA $\left(10^{-4} \mathrm{M}\right)$ & 10 & 50 & 70 & 90 & 28 \\
8-HQ $\left(10^{-3} \mathrm{M}\right)$ & 0 & 20 & 60 & 70 & 20 \\
\hline
\end{tabular}

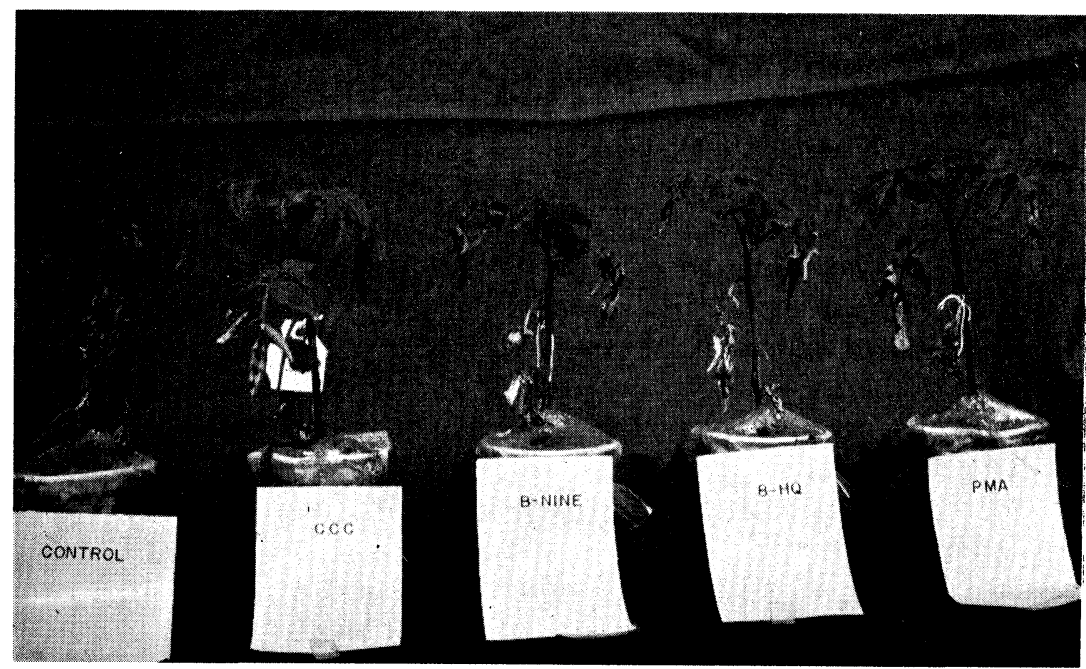

Fig. 3. Wilting of tomato plants as seen at 11 days after cessation of watering. 


\section{Discussion}

The results presented here demonstrate that $\mathrm{CCC}$ and PMA delay the wilting of plants through the chemical closure of stomata. Stomata can be partially closed by a spray of $10^{-4} \mathrm{M}$ solution of several chemicals $\left(Z^{2}\right.$ litch $^{8)}$, Zelitch and Waggoner ${ }^{3)}$ ). It also opens the prospect of practical control of evapotranspiration ${ }^{7)}$. It is also reported that evapotranspiration from a closed stand could be diminished one-sixth by narrowing stomata to half their prior width (Waggoner and Zelitch $\left.{ }^{9}\right)$.

CCC diminishes transpiration to a considerable extent. Immediately after the foliar application, transpiration water loss is reduced to $30 \%$ by PMA treatment. For the next 6 days transpiration is also reduced. If the transpiration during the last days of observation is reduced only due to alteration in the size of the plants, this would be an uninteresting result. This eventuality is tested by relating the grams of water transpired with the dry weight of the plant. The loss of water per gm final dry weight of the plant is significantly reduced due to treatments.: This value is 162 for the control plants, but 132 and 110 for plants treated with PMA and CCC respectively. Thus even at the end of one week, transpiration is significantly diminished beyond any reduction in the size of the plant.

The decline of the curve in Fig. 2 also shows that CCC and PMA significantly reduce transpiration. The reduction in transpiration is related by studying the stomatal opening after treatment with these chemicals. The reduction in stomatal opening is more than $30 \%$ with PMA and about $20 \%$ with CCC even after 14 days of treatment.

If the plant survives for a longer period transpiration reduction might be useful. Prolonging the duration of a well-hydrated condition may possibly allow the plant to survive a brief period of drought which would injure it otherwise. Treatments which reduce transpiration also significantly delay the wilting of plants (Table 4). Even 25 days after cessation of watering when $80 \%$ of the control plants wilt, only 20 to $30 \%$ of the plants wilt when treated with PMA or CCC.

The mode by which these chemicals increase the tolerance of plants to soil drought is unknown. Presumably, through its effect on the closure of stomata these chemicals regulate the water balance of plants. The delayed wilting of plants is perhaps mainly due to the maintenance of a well-hydrated condition. It can be argued that these chemicals regulate the movement of osmotically active material of the guard cells which controls the stomatal opening. It is known ${ }^{10)}$ that CCC inhibits the availability of soluble carbohydrates and PMA inhibits photn-phosphorylation ${ }^{11}$. Inhibition of ATP synthesis prevents stomatal opening ${ }^{12}$. It seems more likely that these chemicals regulate stomatal movement by controlling the metabolic reactions required to increase the turgor of guard cells. The factors requiring the uptake of water by guard cells involve certain biochemical reactions ${ }^{13)}$ which increase the turgidity of guard cells through the utilization of energy in ATP. Thus these chemicals possibly inhibit the factors involved in increasing the turgidity of guard cells, which regulate the stomatal opening.

In the present state of attempts to reduce transpiration water loss and thereby delay the wilting of plants under conditions of soil drought, the main practical problem is the development of improved chemicals of the stomatal closing type. Longer retention and greater specificity are required for these chemicals. The significance of this investigation is that by artificially closing the stomata of plants with the help of chemicals like CCC and PMA, plants can overcome brief periods of soil drought. Whether chemical closure of stomata can increase drought avoidance or tolerance of 
crop plants needs further experimentation.

\section{Acknowledgement}

We are thankful to Dr. I. Zelitch of the Connecticut Agricultural Experiment Station, U.S.A. for supplying the sample of PMA, Cyanamid International, and Naugatuck Chemical Division of the U.S. Rubber company, U.S. A. for supplying us the sample of $\mathrm{CCC}$ and $\mathrm{B}-\mathrm{Nine}$ respectively.

\section{References}

1) Gale, J., and Hagan, R. M., Ann. Rev. Plant Physiol. $17: 269$ (1966).

2) Halevy, A.H., and Kessler, B., Nature (London) $197: 310$ (1963).

3) Cathey, H. M., Ann. Rev. Plant Physiol. $15: 271$ (1964).

4) Zelitch, I., and Waggoner, P.E., Proc. Natl. Acad. Sci. (U. S. A.) $48: 1101$ (1962).

5)—, and ibid. $48: 1297$ (1962).

6)—, Science (U. S. A.) $143: 692$ (1964).

7) Shimshi, D., Plant Physiol. $38: 709$ (1963).
8) Monteith, J.L., in Environmental Control of Plant Growth. L. T., Evans edited. Academic Press, p. 95 (1963).

9) Zelitch, I., Proc. Nat1. Acad.SSci. (U. S. A.) $47: 1423$ (1961).

10) Stoddard, J. L., Jour. British Grassland Soc. $19: 373$ (1964).

11) Siegenthaler, P. A., Physiol. Planta. 19 : 437 (1966).

12) Zelitch, I., Federation Proc. $24: 868$ (1965).

13) - Biol. Rev. $40: 463$ (1965).

\section{摘 要}

D. Mishra, and G.C. Pradhan：化学物質にもとづく

気孔閉塞によるトマトの萎れの遅延.

生長抑制郕 CCC と B-Nine, および殺菌剂 PMA と 8-HQ は, 若いトマト植物体に噴霧すると, 蒸散 による水分損失を 20-35\% 減少させ，気孔の幅を 10-33\% 減少させ，土壌の乾燥による萎机を約 1 週間おく

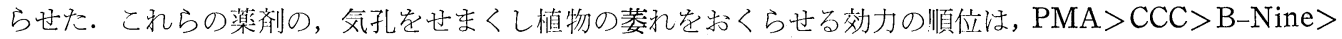
8-HQ である. 土裹乾燥条件下での植物の生存に関係して気孔の薬剂による閉塞の意義と機作とが論じら れた. (Department of Botany, College of Agriculture, Orissa University of Agriculture \& Technology, Bhubaneswar-3, Orissa, India) 